\title{
Changing to continue
}

\author{
Antonio Carlos de Souza Lima ${ }^{1}$ \\ Andréa de Souza Lobo ${ }^{2}$ \\ ' Universidade Federal de Rio de Janeiro (UFRJ), Rio de Janeiro/RJ, Brasil \\ ${ }^{2}$ Universidade de Brasília (DAN/UnB), Brasília/DF, Brasil
}

From the current issue, number 16, Vibrant is adopting the continuous publication system, released in a single annual issue, following the instruments and guidelines presented by SciELO, in response to our growing operational difficulties and the equally rising demands of the latter bibliographic database, as well as those of other databases. Thus, the articles making up the sections of the volume will begin - and continue - to be posted online over the course of the year as they become finalised, with their respective digital object identifier (DOI) codes and their authors identified by their ORCID identity numbers. However, our intention is to continue to publish the entire volume in a single PDF document at the end of each year.

The present issue of Vibrant includes the journal's various regular sections: In memoriam records the sad loss of Sergio Figueredo Ferretti (1937-2018) and commemorates his life and work; the Articles section contains individual texts submitted to the journal, where we highlight the fact that two of them (those by Laura Graziela Ramos and Jair de Souza Ramos) were presented at the same event and dialogue with the same empirical setting. In the next section, the article by Edgard Teodoro da Cunha and Sylvia Cayubi Novaes focuses on how visual images can perform multiple roles, whether by revealing the intentions of their authors, or by activating memories and playing other roles in contemporary life, with the discussion referencing the first recorded images of the Bororo, an indigenous people living in Central Brazil.

The issue also includes three dossiers. The first is a 'mini dossier' composed of two important articles written by Antonio Augusto Arantes Neto, analysing the 'safeguarding mechanism' and its forms of management as proposed by the UNESCO Convention for the Safeguarding of the Intangible Cultural Heritage. The heritage theme also reappears in the Déjà Lu section in the text "Heritage citizenship" by Manuel Ferreira Lima Filho.

The dossier Technique, power, transformation, edited by Fabio Mura and Carlos Emanuel Sautchuk, presents us with the classic discussion on technique - found in anthropology, archaeology and other sciences - as seen through the contemporary proposal of an anthropology of technique, approaching different theoretical proposals, methodological frameworks and empirical universes, in the process highlighting the reinvigoration of a rich universe within our disciplinary field.

Last but not least, we begin the publication of the dossier Anthropology in times of intolerance: challenges facing neoconservatism, coordinated by Lia Zanotta Machado and Antonio Motta, respectively president and vicepresident of the Brazilian Anthropology Association in the two-year period 2017-2018, during which they were confronted with the 'conservative turn' that has assailed Brazilian public life across its multiple levels and dimensions. The dossier will continue in issue 17 of Vibrant and contains important reflections on the contemporary moment through which we are passing.

We wish everyone enjoyable reading and a good holiday season.

Antonio Carlos de Souza Lima and Andréa de Souza Lobo

Editors 


\section{Reference}

SOUZA LIMA, Antonio Carlos. 2017. Editor's Note. Vibrant v.14 n.2 DOI: http://dx.doi.org/10.159o/180943412017v14n2eo1. http://vibrant.org.br/downloads/v14n2/Editorial.pdf

Antonio Carlos de Souza Lima

Federal University of Rio de Janeiro (UFRJ), Rio de Janeiro/RJ, Brazil http://orcid.org/oooo-0001-5260-236X

Email: acslima@gmail.com

Andréa de Souza Lobo

University of Brasília (DAN/UnB), Brasília/DF, Brazil

http://orcid.org/oooo-0001-7525-1953

Email: andreaslobo@yahoo.com.br 